\title{
УДК: 368.016.147:004
}

Скорнякова Олена Володимирівна

викладач вищої категорії циклової комісії комп'ютерних технологій і програмної інженерії Одеський технічний коледж Одеської національної академії харчових технологій, Одеса, Україна dawa78@ukr.net

ORCID: 0000-0002-2136-7747

\section{ФОРМУВАННЯ КОНКУРЕНТОСПРОМОЖНОСТІ МАЙБУТНІХ ІТ-ФАХІВЦІВ ЗАСОБАМИ ІНФОРМАЦЙНО-КОМУНІКАЦІЙНИХ ТЕХНОЛОГІЙ}

\begin{abstract}
Анотація. В статті здійснюється спроба узагальнення ключових підходів до формування конкурентоспроможності майбутніх IT-фахівців засобами інформаційно-комунікаційних технологій. Теоретичні аспекти конкурентоспроможності фахівця представлені у вигляді аналізу загальних проблем конкуренції та конкурентоспроможності. Пропонується визначення поняття «конкурентоспроможність фахівця», уточнюється розуміння конкурентоспроможності стосовно фахівця у галузі IT. Досліджуються умови створення конкурентного освітнього середовища, що забезпечить розвиток конкурентної активності між учасниками освітнього процесу; створення професійно-мотиваційного середовища для активізації процесу професійного зростання майбутнього фахівця; застосування в процесі навчання інноваційних педагогічних технологій; підвищення рівня професійності викладачів і конкурентоспроможності самого закладу освіти. Здійснюється огляд найбільш ефективних педагогічних методів, спрямованих на підвищення конкурентоспроможності IT-фахівців і обгрунтовується необхідність застосування в освітньому процесі інформаційнокомунікаційних технологій. Звертається увага на те, що навчання майбутніх IT-фахівців неможливо без створення специфічних педагогічних умов, що забезпечують процес формування конкурентоспроможності майбутнього фахівця. В першу чергу йдеться про створення конкурентного освітнього середовища, що забезпечить розвиток конкурентної активності між учасниками освітнього процесу; створення професійно-мотиваційного середовища для активізації процесу професійного зростання майбутнього фахівця; застосування в процесі навчання інноваційних педагогічних технологій; підвищення рівня професійності викладачів і конкурентоспроможності самого закладу освіти. Описані в роботі методи із застосуванням інформаційно-комунікаційних технологій, спрямовані на формування фахових компетентностей, комунікативних здібностей фахівця, таких як вміння взаємодіяти з оточенням, працювати в колективі, нести відповідальність перед колективом, що $є$ необхідною складовою конкурентоспроможності фахівця в галузі IT.
\end{abstract}

Ключові слова: інформаційно-комунікаційні технології; компетентісний підхід; конкурентоспроможність; конкурентоспроможність ІТ-фахівців; моделювання освітнього простору

Актуальність. Сучасні темпи розвитку інформаційних технологій вимагають безперервного підвищення кваліфікації спеціалістів в цій сфері. Технологічна та інформаційна глобалізація передбачає відповідність IT-спеціалістів міжнародним стандартам та попиту на певні знання та навички. Відповідності цим вимогам можливо досягти лише за умови постійного безперервного процесу навчання та розвитку у цій галузі з урахуванням нових наукових та технологічних доробок. Вказана проблема безпосередньо пов'язана з організацією освітнього процесу майбутніх фахівців у сфері IT, розробкою ефективних методів та методик, які забезпечують отримання якісної освіти, що відповідає світовим стандартам і дають можливість майбутнім фахівцям стати конкурентоспроможними на ринку праці.

На необхідності розвитку конкурентоспроможності майбутніх фахівців акцентовано увагу в важливих нормативних документах, що регулюють функціонування сучасної системи освіти. Так, в Законі України «Про вищу освіту» зазначено, що державна політика у сфері вищої освіти грунтується на принципах, одним з яких $є$ «сприяння сталому розвитку суспільства шляхом підготовки конкурентоспроможного 
людського капіталу та створення умов для здобуття освіти протягом життя» [4]. Звідси випливає, що організація і зміст процесу професійної підготовки у закладі вищої освіти повинні забезпечувати всебічний розвиток особистості i задоволення потреби суспільства в кваліфікованих конкурентоспроможних фахівцях, що володіють професійно значущими характеристиками і здатні працювати в умовах інформаційного суспільства, що динамічно розвивається.

Незважаючи на це, традиційна практика професійної підготовки орієнтована на формування у студентів спеціальних знань, вмінь та навичок професійної діяльності. Розвитку ж конкурентоспроможних якостей особистості, які б забезпечили продуктивність майбутньої професійної діяльності фахівців з інформаційних технологій і часто змінюються в контексті професійного середовища, приділяється недостатньо уваги. Причину цього ми вбачаємо в тому, що в процесі підготовки майбутніх фахівців 3 інформаційних технологій спостерігається серйозний розрив між теоретичними знаннями і готовністю їх практичного використання, що підсилюється швидким старінням методів дослідження і засобів професійної діяльності.

Такий стан вітчизняної освіти обумовлює необхідність пошуку нових підходів до розвитку конкурентоспроможності майбутніх фахівців 3 інформаційних технологій, здатних до самостійної професійної діяльності, гнучкої адаптації до умов професійного IT-середовища.

Аналіз досліджень і публікацій. Проблема конкурентоспроможності майбутніх фахівців є предметом розгляду педагогіки професійної і вищої освіти, психології, менеджменту, та інших наукових напрямків. Теоретичні аспекти вивчення конкурентоспроможності фахівця представлені у вигляді аналізу загальних проблем конкуренції та конкурентоспроможності (І. Ансофф, Ф. Вірсема, П. Дракер, Б. Карлофф, Ф. Котлер, Ж.-Ж. Ламбен, М. Мескон, М. Портер, М. Треси, Е. Чемберлен, Й. Шумпетер, Лі Якокка, Г.Л. Азоєв, А.І. Архіпова, Г.К. Большакова, О.С. Виханський, О.О. Воронов, Т.П. Гоголева, Г.Б. Клейнер, А.Н. Нестеренко, Ю.Б. Рубін, Е.А. Туманов, Р.А. Фатхутдінов, С.С. Фирсенко, О.П. Челенков, О.Ю. Юданов, та ін.); теоретичних досліджень природи конкурентноспроможності (А. Армстронг, Ф. Котлер, Р. Кох, М. Портер, В.І. Андреев, Л.М. Мітіна, В.І. Шаповалов, Г.К. Максимов); теоретичних, методичних та прикладних досліджень конкурентоспроможності, включаючи оцінку ії рівнів (Д. Аакер, Г.Л. Азоєв, Ю.Ю. Александрова, М.В. Ахматова, Дж. Барні, В.А. Биков та ін.).

В більшості досліджень конкурентоспроможність фахівця розглядається в контексті конкурентоспроможності підприємства (Н.П. Ващекін, О.О. Воронов, М.И. Гельвановський, Л.О. Горшкова, А.Г. Градов, П. Диксон, П. Дойль, М.И. Дзлиєв, П.С. Зав'ялов, Д. Колліс, М.І. Книш, М.Л. Кричевський, М.І. Круглов, Ж.-Ж. Ламбен, Д. Макаліз, Е.В. Минько, С.В. Михєєва, С. Монтгомері, Є.В. Печеркіна, С.В. Попова, М. Портер, К. Прахалад, Ю.Б. Рубін, Т.Ф. Рябова, С.Г. Свєтуньков, П. Степхен, А.К. Тутунджан, Х.А. Фасієв, С. Хант, Г. Хемел, Р.А. Фатхутдінов, О.К. Філатов, А.П. Челенков, Р. Уотермен, А.С. Юхманов и др.).

У вітчизняній педагогіці конкурентоспроможність частіше розглядають в контексті компетентісного підходу, який оріснтований на надбання професійних компетенцій фахівцями певної галузі (О. Антонова, С. Вітвицька, О. Дубасенюк, Н. Ничкало, I. Зязюн, В. Кремень, С. Сисоєва та ін.). Проблеми впровадження інноваційних педагогічних технологій в процес підготовки майбутніх фахівців розглядалися в працях М. Козяра, О. Колгатіна, Г. Райковської, О. Співаковського, Ю. Триус. Особливості професійної підготовки фахівців з IT за кордоном вивчали I. Пододіменко, Р. Шаран та iн.. 
Проте, i до сьогодні проблема конкурентоспроможності фахівців IT-галузі залишається малодослідженою у вітчизняній науці, що обумовлено новизною даного професійного напрямку, високою динамікою розвитку даної галузі в світі і ригідністю змін в педагогіці професійної і вищої освіти. Це обумовлює актуальність проблеми формування конкурентоспроможності майбутніх IT-фахівців, зокрема і засобами інформаційно-комунікаційних технологій.

Мета статті - визначення ключових підходів до формування конкурентоспроможності майбутніх ІT-фахівців засобами інформаційнокомунікаційних технологій.

Потреба у пошуку нових підходів до вирішення проблеми конкурентоспроможності майбутніх ІT-фахівців засобами інформаційнокомунікаційних технологій обумовлена наявністю протиріч між потребою IT-галузі у кваліфікованих спеціалістах, що володіють високим рівнем конкурентоспроможності, i наявною недосконалою системою професійної підготовки фахівців у галузі, відсутністю матеріально-технічної бази, недостатньою науково-методичною розробкою даного процесу в педагогічній теорії та практиці.

Виклад основного матеріалу. Поняття «конкурентоспроможність фахівця» 3'явилося в педагогічній науці в останні десятиліття. Актуальним воно стало разом 3 переходом економіки на ринкові відносини. Сучасний роботодавець висуває вимоги не лише до професійних знань і компетенцій працівника, але й до його особистісних якостей, які доповнюють набір професійних знань, умінь, навичок. Проте однозначного підходу до проблеми конкурентоспроможності фахівця в сучасній науці дотепер не існуе.

Спираючись на економічне трактування конкурентоспроможності товарів і послуг, доцільно екстраполювати дане поняття в сферу підготовки фахівців і конкретизувати його. На нашу думку, конкурентоспроможність фахівця $€$ інтегративною характеристикою, що забезпечує більш високий професійний статус, більш високу рейтингову позицію на відповідному галузевому ринку праці, стійкий високий попит на професійні послуги (запитаність); вона визначається особливостями особистості фахівця і якістю його професійної підготовки. Рівень конкурентоспроможності залежить від ступеня відповідності особистісних якостей і професійних знань, умінь і навичок конкретного фахівця об'єктивним вимогам професійної діяльності і соціальноекономічних умов [12, С. 30].

Здебільшого конкурентоспроможність фахівця розглядають 3 позицій особистісного, діяльнісного, компетентісного підходів. В контексті особистісного підходу (В.Андреєва, Н.Борисова, І.Драч, Г.Дмитренко, Є.Климова, А.Маркова.) досліджуються структура та характеристики конкурентоспроможних якостей особистості, а конкурентоспроможність визначається як набір відповідних якостей, що відповідають вимогам професії. В контексті діяльнісного підходу, конкурентоспроможність фахівця визначається як активна складова діяльності людини, що спрямована на предмет праці, на соціальне середовище і самого себе. Основу конкурентоспроможності з точки зору діяльнісного підходу складають знання, уміння i навички професійної діяльності та наявність професійного досвіду.

На думку А.Н. Кара, конкурентоспроможність фахівця - це взаємообумовлена єдність його мотиваційних, кваліфікаційних, особистісних і ділових характеристик, що забезпечують високий рівень теоретичної підготовки, володіння практичними навичками професійної діяльності, вільну орієнтацію в суміжних областях, здатність адаптуватися в професійному середовищі, відповідність вимогам роботодавця i внутрішній баланс душевних і фізичних сил [7, С. 15]. Натомість Ю.В. Андріяко в своїх роботах, пропонує інший критерій визначення конкурентоспроможної особистості - 
здатність швидко і безболісно адаптуватися до постійних змін соціальних умов, науковотехнічного прогресу і нових видів діяльності та форм спілкування за умови збереження позитивного внутрішнього психоенергетичного потенціалу і гармонії [1, С. 34-36]. На думку А.Я. Кібанова, конкуренція фахівців - це основна умова для забезпечення високого рівня професіоналізму і компетентності, розвитку особистих якостей, інноваційного та мотиваційного потенціалу [8, С. 13].

Тривалий час система освіти основним своїм завданням вбачала передачу майбутньому фахівцю знань, необхідних для виконання професійної діяльності. Проте в сучасних умовах такого підходу до навчання майбутніх фахівців виявилося недостатньо. Сьогодні, в епоху технологізації і глобалізації, одним із ключових завдань закладів вищої освіти $€$ забезпечення конкурентоспроможності молодих фахівців, розвитку конкурентних якостей особистості. Саме вирішення цієї задачі займає одне 3 центральних місць в освітніх реформах. Сьогодні підготовка кадрів, які володіють не лише знаннями, які динамічно змінюються в інформаційному середовищі, а й навичками ефективного управління інноваційними процесами, які вміють розробляти i впроваджувати інноваційні проекти є пріоритетною метою вищої освіти. На перший план висуваються проблеми забезпечення конкурентоспроможності національних економік, галузей виробництва, підприємств і фахівців [6].

Розглядаючи конкурентоспроможність фахівця в сфері IT, слід враховувати, в першу чергу, специфіку галузі, іiі основні характеристики, до яких можемо віднести динамічність, технологічність, інтеграція в усі галузі економіки. Зокрема, сьогодні спостерігається суттєве розширення комп'ютеризації підприємств, загальнодоступність мережі Інтернет, збільшення потреби промисловості і бізнесу у програмній продукції та технологічних послугах [11].

Сучасний IT-ринок характеризується помітним зростанням професіоналізму серед IT-фахівців; зростанням інтересу організацій та підприємств до автоматизації прийняття бізнес-рішень для підвищення ефективності своєї роботи, управління інформацією та збереженням даних 3 метою отримання конкурентних переваг; прагненням до збільшення прозорості бізнесу та інвестиційної привабливості [2, С. 102].

Тож, на нашу думку, навчання майбутніх IT-фахівців має здійснюватися 3 урахуванням вказаних вимог, що неможливо без створення специфічних педагогічних умов, що забезпечують процес формування конкурентоспроможності майбутнього фахівця в галузі IT. В першу чергу, йдеться про створення конкурентного освітнього середовища, що забезпечить розвиток конкурентної активності між учасниками освітнього процесу; створення професійно-мотиваційного середовища для активізації процесу професійного зростання майбутнього фахівця; застосування в процесі навчання інноваційних педагогічних технологій; підвищення рівня професіоналізму викладачів i конкурентоспроможності самого закладу освіти.

На думку Л.І. Лепе навчання майбутніх ІT-фахівців повинно здійснюватись в узгодженні з поширенням нових інформаційних технологій і своєчасним їх включенням в освітній процес для формування професійної компетентності, забезпечуючи майбутнім фахівцям конкурентоспроможність в умовах стрімкого розвитку IT-індустрії. Вчений пропонує використовувати 3 цією метою технологію випереджаючого навчання інформаційних технологій майбутніх IT-фахівців, що має реалізовуватися в трьох напрямках:

- актуальності й запитаність відповідних інформаційних технологій;

- високої якості професійної підготовки майбутніх фахівців 3 інформаційних технологій;

- інтенсифікації процесу навчання з використанням інформаційно-комунікаційних технологій та інформаційних технологій моделювання [10]. 
Інформаційно-комунікаційні технології (ІКТ) - сукупність технологій, що забезпечують фіксацію інформації, іiї обробку і обмін (передачу, поширення, розкриття). Якісне навчання сучасного фахівця в галузі IT не представляється можливим без використання IКТ. На це вказують і рекомендації до професійної підготовки в галузі інформатики та інформаційних технологій, що були визначені CC2001 [13] і СС2005 [14]. Дані документи отримали розвиток у вигляді додаткових рекомендацій і версій, які послужили основою для більш глибокого розуміння процесу і конкретизації у вигляді навчальних програм і планів. У даних документах підкреслюється, що навчальний досвід суттєво відрізняється від виробничого, і викладачі повинні прагнути полегшити процес переходу із закладу освіти в світ реального бізнесу, моделюючи для студентів реальне робоче середовище, навчаючи їх працювати в команді, забезпечуючи їх досвідом участі в реальному проекті.

Моделювання умов майбутнього професійного середовища - це створення можливості вільних, необмежених дій студента, де він може вільно обирати методи і засоби для застосування своїх знань. При цьому він повинен мати можливість консультуватися 3 викладачами та експертами. Але основна мета моделювання - це формування самостійного, повноцінного фахівця, здатного оцінити свої можливості в ситуації, максимально наближеній до реальної, визначати конкретну спеціалізацію своєї майбутньої професійної діяльності [12]. Моделювання дозволяє організувати і командну роботу, опанувати прийоми планування, бюджетування, розвивати організаторські i комунікаційні навички.

До найбільш ефективних методів навчання сьогодні відносять case study i комп’ютерні симуляції (навчальні ділові ігри, побудовані на базі спеціального ПЗ). Ефективність вказаних методів підтверджено як експериментальним шляхом в дисертаційному дослідженні Л. Зубик та інших дослідників, так і роками їх успішного використання в педагогічному процесі [5]. Case-study (від англ. «case»- випадок) - метод навчання на основі аналізу реальної ситуації у бізнесі. Метод виник ще на початку XX століття у школі бізнесу Гарвардського університету, де активно застосовується i сьогодні, а його метою є навчити студентів аналізувати інформацію (індивідуально або групою), сортувати iï для вирішення поставленого завдання, виявляти ключові проблеми, генерувати альтернативні шляхи для їх вирішення, обирати оптимальні варіанти і формувати програми дій.

Сутність методу case-study описує в своїй дисертаційній роботі Л. Зубик, розуміючи його як самостійну діяльність студентів у штучно створеному професійному середовищі, яке стимулює поєднання теоретичної підготовки і практичних умінь, необхідних для творчої професійної діяльності. Студентам пропонується осмислити ситуації професійної діяльності, які передбачають необхідність вирішення проблеми, у процесі чого відбувається актуалізація засвоєних знань. Включення методу кейсів до освітнього процесу закладу вищої освіти, на думку автора, дозволяє: опрацьовувати інформацію невеликими блоками, що знижує міру невизначеності в умовах ліміту часу; формувати у студентів глибоке осмислення теоретичних концепцій; реалізувати нові моделі діяльності; формувати навички найпростішого узагальнення значної кількості інформації [5, С. 125].

Комп'ютерні симуляції - це тип динамічних кейсів, в яких ситуація не фіксується, а кожного разу моделюється користувачем. Технологія дозволяє здійснювати візуалізацію об'єктів, ситуацій, навчального матеріалу; моделювання та імітацію об'єктів, які досліджують; проводити віртуальні лабораторні і практичні роботи; відпрацьовувати необхідні навички і застосовувати їх у динамічних ситуаціях [9].

Підвищення якості підготовки конкурентних кваліфікованих фахівці можна досягти поєднанням педагогічних інновацій 3 інформаційно-комунікативними 
технологіями (ІКТ). Прикладом такого вдалого та ефективного поєднання є веб-квести, що втілюють в собі механізми проектного навчання на основі ІКТ. Над питанням ефективності впровадження в освітній процес інформаційно-комунікаційних технологій працювали Т.М. Герлянд, М.Ю. Кадемія, .І. Пометун, О.В. Шестопалюк, А.В. Хуторський.

Веб-квест (webquest) - це проблемне завдання з елементами рольової гри, для виконання якого використовуються інформаційні ресурси Інтернету. Ми будемо розглядати веб-квест як вид Інтернет-проекту, що дає можливість ефективно використовувати інформацію, яка знайдена в мережі Інтернет. Технологія веб-квесту передбачає роботу в малих групах, розвиває комунікативні навички, уміння працювати в команді [3, С. 67].

В процесі проведення веб-квесту учасники виконують ряд завдань в невеликих групах (4-5 осіб), шляхом жеребкування дізнаючись, яке питання команда досліджуватиме. Кожний з учасників групи має обрати одну з ролей, з числа тих, які пропонуються (дослідник-пошуковець, що шукає необхідну для мікрогрупи інформацію, узагальнюючи іiі зміст; редактор, який готує доповідь, користуючись інформацією, наданою дослідником-пошуковцем; графічний дизайнер, який готує презентацію, продумує концепцію представлення продукту мікрогрупи та презентації, стиль, зміст та наповнення слайдів; спікер, який буде доповідати). Кожна роль передбачає виконання певних завдань, для їхнього виконання використовуються посилання в мережі Інтернет. Після завершення всіх завдань складається підсумковий звіт-презентація. Представники підгруп представляють власні результати роботи та захищають їх. Після презентацій оцінюються досягнення власної підгрупи та інших. Повідомляються результати i підводяться підсумки. Учасникам пропонуються вправи на рефлексію. Рефлексія передбачає самоаналіз та самооцінку учасниками своєї проектної діяльності, для чого викладач готує рефлексивні вправи та завдання. У ході рефлексії обговорюються такі питання як:

- досягнення встановленої мети;

- якість виконання завдань та отриманих результатів;

- змістове наповнення проектних продуктів;

- складність і особливості виконаних завдань тощо.

Необхідно підкреслити, що протягом усього веб-квесту викладач має підтримувати учасників, коригувати їхню діяльність, надавати потрібні міні-консультації, пом'якшувати атмосферу в аудиторії, відстежувати часові обмеження тощо.

За твердженням Т.М. Герлянд, використання веб-квест технології сприяє підвищенню мотивації до самонавчання та самоорганізації; розвитку та реалізації креативного потенціалу; підвищенню особистісної самооцінки та розвитку особистісних професійно-важливих якостей; формуванню здатності визначати найбільш раціональний варіант вирішення проблеми і обгрунтовувати свій вибір; отриманню навичок роботи в команді (планування, розподіл функцій, конструктивне спілкування, взаємодопомога, взаємоконтроль); формуванню нових компетентностей (оформлення результатів своєї роботи у вигляді веб-сторінок або сайтів, слайд-шоу, буклетів, постерів чи фото, відеорепортажів); формуванню готовності до публічних виступів (захист проектів 3 виступами авторів, з питаннями, дискусіями) [3].

Такі форми роботи сприяють не лише формуванню фахових компетентностей, але й комунікативних здібностей фахівця, таких як вміння взаємодіяти 3 оточенням, працювати в колективі, нести відповідальність перед колективом, що є необхідною складовою конкурентоспроможності фахівця.

Висновки. Таким чином, можемо зробити висновок, що формування конкурентоспроможності майбутніх ІT-фахівців - це складний процес, який включає в 
себе не лише отримання необхідних для майбутньої професійної діяльності знань, умінь та навичок, але й формування комплексу особистісних якостей, відповідної мотивації, здатності працювати в команді і застосовувати свої знання в реальних професійних ситуаціях. Підвищення конкурентоспроможності майбутніх IT-фахівців можливе за умов створення у закладі вищої освіти відповідних педагогічних умов і застосування педагогічних і технологічних інновацій. Навчання майбутніх IT-фахівців повинно здійснюватись в узгодженні 3 поширенням нових інформаційних технологій i своєчасним їх включенням в освітній процес при формуванні професійної компетентності, забезпечуючи конкурентоспроможність в умовах стрімкого розвитку ІТ-індустрії.

Описані методи роботи із застосуванням інформаційно-комунікаційних технологій, спрямовані на формування фахових компетентностей, комунікативних здібностей фахівця, таких як вміння взаємодіяти з оточенням, працювати в колективі, нести відповідальність перед колективом, що $\epsilon$ необхідною складовою конкурентоспроможності фахівця в галузі IT.

\section{СПИСОК ВИКОРИСТАНИХ ДЖЕРЕЛ}

1. Андрияко Ю.В. Конкурентоспособность выпускника высшего учебного заведения как организационно-педагогическая проблема. Вектор науки ТГУ. 2010. № 1(1). C. 34- 36.

2. Варфоломеева Т.Н., Мовчан И.Н. Информационная образовательная среда как основа повышения конкурентоспособности выпускников ВУЗА. Разработка инновационных механизмов повышения конкурентоспособности выпускников ИТспециальностей вуза в условиях монопромышленного города: сб. науч. ст. Магнитогорск, 2012. С. 100-105.

3. Герлянд Т.М., Кулалаєва Н.В., Пащенко Т.М., Романова Г.М., Романов Л.А. Вебквест у професійному навчанні: методичні рекомендації; за заг. редакцією Т.М. Герлянд. К.: ІПТО НАПН України, 2016. 141 с.

4. Закон України від 01.07.2014 р. № 1556-VII «Про вищу освіту». URL: https://zakon.rada.gov.ua/laws/show/1556-18_(дата звернення: 19.10.2019).

5. Зубик Л. В. Формування професійних компетентностей майбутніх бакалаврів 3 інформаційних технологій у процесі вивчення фахових дисциплін: дис. канд. пед. наук. Рівне, 2016. 342 с.

6. Кара А. Н., Кузнецова Е. Ю. Пирамида конкурентоспособности рабочей силы: уровни построения и их логическая взаимосвязь. Проблемы современной экономики, 2011. №1 (37). С.76-80.

7. Кара А. Н. Оценка конкурентоспособности специалистов на региональном рынке труда: теория, методология, практика: Автореф. дис. докт. экон. наук. Москва, 2012. $44 \mathrm{c.}$

8. Кибанов А.Я. Экономика и социология труда. М.: Инфра-М, 2009. 584 с.

9. Курзаева Л.В. Структурно-функциональная модель развития конкурентоспособности будущего IT-специалиста в процессе профессиональной подготовки в вузе: организационно-управленческий аспект. Современные проблемы науки и образования, 2012. №6. URL: http://www.scienceeducation.ru/ru/article/view?id=7424 (дата звернення: 19.10.2019).

10. Лепе Л.И. Когерентная система обучения информационным технологиям как компонента опережающего образования. Информационные технологии в образовании ИТО-2005: материалы конгресса конф. URL: http://ito.edu.ru/2005/ Moscow/I/1/I-1-5036.htm (дата звернення: 19.10.2019). 
11. Славова Л.Д. Конкурентоспособность молодого специалиста в современных реалиях: URL: http://rusnauka.com_(дата звернення: 19.10.2019).

12. Хазова С. А. Конкурентоспособность специалистов и профессионализм: сопоставление феноменов. URL: http://www.fan-nauka.nar od.ru/2008-1.html (дата звернення: 19.10.2019).

13. Computing Curricula 2001. Association for Computing Machinery and Computer Society of IEEE.

14. Computing Curricula 2005. Associati on for Computing Machinery and Computer Society of IEEE.

\title{
FORMATION OF COMPETITIVENESS OF FUTURE IT SPECIALISTS BY MEANS OF INFORMATION AND COMMUNICATION TECHNOLOGIES
}

\author{
Olena Skorniakova \\ teacher of the department \\ Computer technology and software engineering, \\ Odessa National Academy of Food Technologies, Odesa, Ukraine \\ dawa78@ukr.net \\ ORCID: 0000-0002-2136-7747
}

\begin{abstract}
The article attempts to summarize the key approaches to the formation of competitiveness of future IT specialists by means of information and communication technologies. The theoretical aspects of a specialist's competitiveness are presented in the form of an analysis of common problems of competition and competitiveness. The definition of the term "specialist competitiveness" is offered, the understanding of competitiveness in relation to the specialist in the field of IT is specified. The review of the most effective pedagogical methods aimed at increasing the competitiveness of IT specialists is carried out and the necessity of application in the educational process of information and communication technologies is substantiated. Attention is drawn to the fact that training of future IT specialists is impossible without the creation of specific pedagogical conditions that provide the process of forming the future competitiveness of the future specialist in the field of IT. Experienced through a competitive outcome that ensured competitiveness between participants in the process; to create vocational-motivational work to activate the process of professional activity of the future time; application of innovative pedagogical technologies in the process of teaching; the success of professionals and the competitiveness of training itself. First of all, it is about creating a competitive educational environment that will ensure the development of competitive activity between the participants of the educational process; creation of a professionalmotivational environment for activating the process of professional growth of the future specialist; application of innovative pedagogical technologies in the process of teaching; raising the professional level of teachers and the competitiveness of the educational institution itself. Methods with the use of information and communication technologies are described in the work, aimed at the formation of professional competences, communicative abilities of a specialist, such as the ability to interact with the environment, work in a team, be accountable to the team, which is a necessary component of the competitiveness of a specialist in the field of IT.
\end{abstract}

Keywords: information and communication technologies; competent approach; competitiveness; competitiveness of IT specialists; modeling of educational space

\section{REFERENCES (TRANSLATED AND TRANSLITERATED)}

1. Andriyako, Yu. (2010). Competitiveness of a graduate of a higher education institution as an organizational-pedagogical problem. Vector of the TSU Science, 1 (1), 34-36 (in Russian)

2. Bartholomew, T. \& Movchan, I. (2012) Informational educational environment as a basis for increasing the competitiveness of university graduates. Development of innovative mechanisms for increasing the competitiveness of graduates of the IT-specialties of the university in the conditions of a mono-industrial city: Sat. scientific Art. Magnitogorsk, 100-105 (in Russian) 
3. Gerland, T., Kulalaeva, N., Pashchenko, T., Romanova, G., \& Romanov, L. (2016) Webquest in Vocational Training: Guidelines; for the total. edited by T.M. Herlands. K .: IPTO NAPS of Ukraine, 141p. (in Ukrainian)

4. Law of Ukraine dated 01.07.2014 No. 1556-VII “On Higher Education" (2014). https://zakon.rada.gov.ua/laws/show/1556-18 (in Ukrainian)

5. Zubik, L. (2016) Formation of professional competencies of future bachelors in information technology in the process of studying professional disciplines: diss. Cand. ped. of sciences. Exactly, 342 p. (in Ukrainian)

6. Kara, A. \& Kuznetsova, E. (2011). The pyramid of labor force competitiveness: levels of construction and their logical relationship. Problems of Modern Economics, 1(37) (in Russian)

7. Kara, A. (2012). Assessment of the competitiveness of specialists in the regional labor market: theory, methodology, practice: Author's abstract. diss. Doc. econom. of sciences. Moscow, 2012. 44 p. (in Russian)

8. Kibanov, A. (2009). Labor economics and sociology. M.: Infra-M, 584 p. (in Russian)

9. Kurzaeva, L.(2012). Structural-functional model of development of competitiveness of the future IT-specialist in the process of vocational training in the university: organizationalmanagerial aspect. Modern problems of science and education, 6

http: //www.scence-education.ru/article/view? Id = 7424 (accessed 19.10.2019). (in Russian)

10. Lepe, L. (2005). A coherent system of information technology training as a component of advanced education. Information technologies in ITO-2005 education: materials of congress conf.

http: // it o.edu.ru / 2005 / M osc ow / I / 1 / I-1-5036.htm (in Russian)

11. Slavova, L. (2014). Competitiveness of a Young Specialist in Modern Realities http: //rusnauka.com (in Russian)

12. Khazova, S. (2008). Competitiveness of specialists and professionalism: juxtaposition of phenomena http: //www.fan-nauka.nar од.ru / 2008-1.html (in Russian)

13. Computer Curricula 2001 (2001). Associaion for Ccomputing Machines and Computer Societe of IEEE.

14. Computer Curricula 2005 (2005). Associations on for Computing Machines and Computer Societe of IEEE. 